\title{
APLIKASI TIKTOK MENJADI MEDIA HIBURAN BAGI MASYARAKAT DAN MEMUNCULKAN DAMPAK DITENGAH PANDEMI COVID-19
}

\author{
Agia Dwi Visi Utami ${ }^{1}$, Suci Nujiana ${ }^{2}$, Dasrun Hidayat ${ }^{3}$ \\ ${ }^{1,3}$ Universitas Adhirajasa Reswara Sanjaya \\ ${ }^{2}$ Universitas Subang \\ Email: agiadvu@gmail.com
}

\begin{abstract}
ABSTRAK
Penelitian ini berjudul, "Fenomena Aplikasi Tiktok Menjadi Media Hiburan Bagi Masyarakat Dan Memunculkan Dampak Ditengah Pandemi Covid-19" Tujuan dari penelitian ini yaitu sebagai alat untuk mengetahui fenomena dari pengguna aplikasi Tiktok ditengah pandemi Covid-19, bagaimana motif pengguna aplikasi Tiktok, tindakan pengguna aplikasi Tiktok serta bagaimana makna penggunaan aplikasi Tiktok ditengah pandemi Covid-19. Metode dan cara penelitian yang telah digunakan peneliti dalam melakukan penelitian ini adalah metode Fenomenologi, dengan jenis penelitian kualitatif, dan teknik pengumpulan data hasil penelitian dilakukan dengan cara wawancara secara online. Wawancara yang dilakukan melibatkan beberapa pengguna aplikasi Tiktok itu sendiri. Berdasarkan hasil penelitain, diperoleh gambaran bahwa motif pengguna aplikasi Tiktok ditengah pandemi Covid-19 ialah sebagai media hiburan. Selanjutnya, tindakan pengguna aplikasi Tiktok untuk mengekspresikan kreativitasnya. Kemudian, makna penggunaan aplikasi Tiktok ditengah pandemi Covid-19 adalah sebagai aplikasi untuk bermedia sosial dan melalukan edit video menggunakan effects yang diperuntukan sebagai hiburan. Adapun Saran-saran yang dapat disampaikan oleh peneliti kepada pengguna aplikasi Tiktok adalah jangan mengikuti semua trend yang ada di aplikasi Tiktok menjadi gaya hidup, tetapi jadikanlah aplikasi ini sebagaimana fungsinya, yaitu untuk mengekspresikan diri dengan membuat video unik dan kreatif. Sebaiknya gunakan teknologi yang ada tanpa mengambil efek buruk yang dapat ditimbulkan.
\end{abstract}

Kata Kunci: Covid-19, Aplikasi Tiktok, Hiburan

\section{TIKTOK APPLICATION BECOMING ENTERTAINMENT MEDIA FOR THE COMMUNITY AND INCREADING IMPACT IN THE MIDDLE OF PANDEMIC COVID-19)}

\begin{abstract}
This research is entitled, "Phenomences Of Tiktok Application Becoming Entertainment Media For The Community And Increading Impact In The Middle Of Pandemic Covid-19," The purpose of this research which is as instrument for discovering phenomena from using Tiktok application in the middle of pandemic Covid-19, how the motive from using Tiktok application, the act from using Tiktok application, and how the meaning of using Tiktok application in the middle of pandemic Covid-19. The method and the way for the research that was used for research in processes this researching is Fenomenology methode, with the kind of qualitative research, and technuique of data accumulation from the result of research with online interview. This interview entangled some of user Tiktok. Based on the result of this research. However from the research we are facile that the motive of user Tiktok is for media entertainment. In the next is the action user Tiktok for expression their creativity. After wards this meaning of using Tiktok in the middle of Covid-19 as for social in media and editing video with visual effect for entertainment. As for advice that can be to say from this research is don't be followed all the trend of Tiktok application becoming lifestyle, but create this application as its function that isfor expression their self with make unique and creative video. And advisable using the technology without an unfortunate ripple effect..
\end{abstract}

Keywords: Covid-19, Tiktok Aplications, Entertainment

Publish by Communication Science Program, Social Politic Faculty Universitas Muhammadiyah Buton. 
Korespondensi: Agia Dwi Visi Utami. ARS University. Jl. Sekolah Internasional no 1-6 Antapani, Bandung, Indonesia, 40282. No. Hp, Whatsapp: 0895-3528-8810-3 Email: agiadvu@ gmail.com

\section{PENDAHULUAN}

Dunia saat ini sedang dihebohkan dengan satu pandemi Covid-19. Covid-19 kepanjangan dari CO (Corona), VI (Virus), D (Disease) dan 19 yang mana Covid-19 terdeteksi tahun 2019. Awal mula virus ini muncul pertamakali di indentifikasi dari flu biasa pada tahun 1960. Hingga sampai tahun 2002, virus Covid19 belum juga dianggap sebagai virus yang serius. Tetapi setelah ditemukannya SARS-Cov (Severe Acute Respiratory Syndrome) di China, para peneliti memfokuskan pada penyebab terjadinya hal tersebut diakibatkan oleh bentuk baru dari corona. (Habibibullah, 2020)

Tahun 2012, terjadi pula wabah yang hampir sama seperti SARS-Cov yaitu MERS-Cov (Middle East Respirotary Syndrome) di Timur Tengah. Diambil dari kedua fenomena tersebut disimpulkan bahwa corona bukan jenis virus yang tidak beradaptasi (stabil), ia bisa saja beradaptasi lebih ganas hingga mengakibatkan kematian. (Ladimo, 2020)

Prof Soewarno, mengatakan bahwa virus Covid-19 bukan virus jenis baru melainkan perkembangan atau mutasi dari virus sebelumnya yaitu corona yang berkembang menjadi SARS-Cov dan MERS-Cov. Karateristik virus corona bersifat Single-stanted RNA yang menyebabkan ia lebih mudah bermutasi dan berkembang. (HAKIM, 2020)

Berbagai polemik penyebab Covid-19 yang tersebar di berbagai media dapat disimpulkan bahwa penyebab dari Covid-19 ini berbeda dengan virus sebelumnya yaitu, SARS-Cov berasal dari kelelawar dan MERS-Cov yang disebabkan oleh unta. Covid-19 diduga virus yang mengalami perpindahan dari kelelawar ke ular dan yang pada akhirnya sampai di manusia.

Sama seperti dua kasus sebelumnya virus Covid-19 itu sendiri merupakan virus yang mengganggu pernapasan manusia. Covid-19 juga diduga muncul pertama kali di Kota Wuhan tepatnya di China pada bulan Desember 2019. Covid-19 mewabah antar manusia dengan manusia melalui air liur yang keluar dari tubuh dan tidak sengaja menyentuh permukaan tangan. Selanjutnya, orang yang tidak terinfeksi virus dapat tertular apabila berhubungan langsung dengan orang yang sudah terkontaminasi.

Organisasi Kesehatn Dunia (WHO) menetapkan bahwa Covid-19 sebagai jenis virus yang menyebar dan mewabah diseluruh dunia atau pandemi global karena penyebarannya yang cepat dan sudah menyentuh hampir 198 negara. Seseorang yang terinfeksi Covid-19 akan merasakan gejala seperti demam, batuk, nyeri otot, kesulitas bernafas hingga kelelahan. Namun jika orang yang terinfeksi memiliki penyakit bawaan seperti gagal jantung, infeksi paru-paru, maka akan memperarah kondisi tubuh hingga menyebabkan kematian.

Virus Covid-19 sudah menginfeksi lebih dari 100 juta kasus di seluruh dunia (Selasa, 16 Februari 2021). Total kasus positif Covid-19 di Indonesia telah menembus 1 juta kasus. Angka menambahnya kasus baru terbilang masih flutiatif karena adanya peningkatan kasus yang signifikan. 
Akibat penularan yang sangat cepat, berbagai negara masih menerapkan kebijakan-kebijakan dari kepemimpinan mereka masing-masing. Diantaranya melakukan tes secara berkala terhadap warga negaranya yang memiliki gejala baik ringan ataupun serius. Korea Selatan telah berhasil mengurani pandemi ini dengan cara melakukan tes kepada lebih dari 10.000 orang perharinya. Banyak negara juga yang melakukan isolasi kepada warga negara nya yang terinfeksi. Hal tersebut dianggap efektif karena mencegah penuralan yang lebih besar kepada orang yang sehat. Social distancing juga menjadi salah satu cara yang dilakukan hampir seluruh negara yang terinfeksi untuk memperingati warga negara nya menjaga kesehatan dan mencegah bermutasinya virus ini dengan cepat.

Untuk menghindari penyebaran Covid-19 tak sedikit negara yang mengambil kebijakan lockdown. Lockdown sendiri merupakan keadaan yang tidak mengizinkan orang untuk bisa masuk atau pergi meninggalkan sebuah tempat dengan mudah karena alasan sesuatu yang darurat. Australia, Austria, Denmark, Inggris, Yunani, Jerman, Israel, Italia, Irlandia, Belanda dan Polandia merupakan negara yang menerapkan kebijakan lockdown.

Sebuah negara yang menerapkan kebijakan lockdown memiliki keputusan yang sulit, karena bisa berdampak terhadap banyak sektor yang mempengaruhi ekonomi negara. Sektor wisata merupakan salah satu yang akan mengalami dampak dari kebijakan lockdown tersebut. Pasalnya saat sektor wisata di tutup turis bahkan domestik dilarang untuk berpergian ke tempat acara dan wisata. Seperti, disney, konser-konser internasional, festival music, liga olahraga ditangguhkan bahkan dibatalkan yang pada akhirnya menyebabkan kerugian bagi orang-orang yang terlibat didalamnya.

Sektor Manufaktur menjadi dampak akibat lockdown juga contohnya di Italia, di dominasi oleh perusahaan yang produsen fashion mengalami penurunan setelah pemerintah Italia menetapkan kebijakan lockdown. Sektor Ekonomi merupakan salah satu sektor yang mengalami penurunan yang signifikan dari sektor-sektor lain yang mengalami dampak. Di bidang ini investor-investor akan perlahan mundur bahkan menghilang. Menurut VOA News, di Manilla pemberlakuan lockdown memangkas pertumbuhan ekonomi nasional.

Sektor Sosial tentunya terkena dampak juga karena aktivitas masyarakat dibatasi sehingga mereka dilarang berkumpul termasuk ibadah. Vatikan sudah melarang ibadah pekan suci dan paskah hingga Arab Saudi yang membuat warga muslim didunia mengurungkan niat untuk ibadah umrah Terakhir, Sektor pangan juga menjadi langka akibat domino dari sektor lainnya. Bahkan di China beberapa orang merasa bingung jika persediaan makanan mereka habis.

Indonesia telah memberlakukan PSBB, PPKM, dan seruan dirumah saja agar mencegah penyebaran Covid-19 tidak meluas. Diberbagai daerah di Indonesia sudah di berlakukan PSBB (Pembatasan Sosial Berskala Besar). Diseluruh penjuru Indonesia pembelajaran tingkat TK, SD, SMP, SMA/K sampai 
Mahasiswa/I sudah digantikan dengan program pemerintah yang belajar dirumah saja. Para karyawan yang bekerja sudah digantikan menjadi Work From Home atau WFH.

Pemerintah memberikan kebijakan terhadap masyarakat agar diam dirumah menjadi cara yang efektif. Masyarakat diam dirumah menggunakan cara satu-satu nya untuk mengetahui dunia luar menggunakan Internet. Mendapatkan informasi terkait Covid-19, belajar, bekerja hingga hiburan sekalipun menggunakan media massa yang sudah ada dan mudah untuk didapatkan.

Adanya Media Massa disekitar masyarakat memiliki peran yang penting. Dimulai dari peristiwa keseharian, hingga hal-hal yang memiliki dampak besar bagi perubahan gaya hidup masyarakat didunia. Semua hal itu dapat dilihat dan diakses melalui media massa. Beberapa dampak menjadi menarik perhatian masyarakat. (Damayanti, 2019)

Pada awalnya Media massa dikenal dengan sebutan pers yang berasal dari bahasa Belanda yang jika diartikan kedalam bahasa Inggris yang artinya press. Pers yang diartikan dalam Bahasa Indonesia sebagai media cetak atau penyiaran secara tercetak atau publikasi secara cetak. Namun, secara luas arti pers adalah segala hal yang mengenai penerbitan, seperti media massa, elektronika, televisi siaran, radio siaran dan bahkan segala informasi yang tercetak secara visual di internent yang sering kita jajaki juga termasuk dalam pers.

Fenomena pada saat ini munculnya Aplikasi yang sudah banyak pengunduhnya, yaitu Aplikasi Tiktok. Aplikasi Tiktok adalah salah satu aplikasi jejaring sosial dan platform music video dari negara Tiongkok yang pertamakali diluncurkan pada bulan September tahun 2016 oleh Zhang Yiming, pendiri aplikasi Toutiao. Menurut data AppAnnie pada tahun 2019 sudah 625 juta pengguna aktif diseluruh dunia. Munculnya pandemi Covid-19 yang sedang mewabah didunia, Tiktok meningkat hingga 2 miliar pengguna. Jumlah nya melebihi total user yang mengunduhan aplikasi Instagram, 1,5 miliar secara global. (katadata.co.id)

Aplikasi ini ditengah pandemi Covid-19 semakin banyak orang menggunakan sebagai salah satu media hiburan, cara mengekspresikan kekesalan, mengeluarkan kreativitas, untuk menghabiskan waktu dirumah sampai menjadi tempat untuk berolahraga dirumah. Konten yang ada didalam aplikasi Tiktok ini mulai dari musik, video, visual, hingga dance didalam nya.

Masyarakat mengahabiskan waktunya untuk tetap berdiam diri dirumah dan melakukan kegiatan, membuat video Tiktok contohnya sebagai penghilang rasa bosan. Pengguna Tiktok tidak hanya dari kalangan biasa tapi juga selebritis manca negara juga menggunakan aplikasi tersebut. Penguduh aplikasi Tiktok berasal dari berbagai kalangan bahkan lansia pun banyak yang menggunakan aplikasi Tiktok ini.

Aplikasi Tiktok juga membantu jajaran pemerintah, para medis dan influencer untuk mensosialisasikan pesan berupa himbauan dan cara menggunakan konten yang menjadi sasaran untuk disebarluaskan oleh pemerintah, para medis dan influencer kepada masyarakat. 
Dari fenomena Tiktok ini bukanlah semata karena aplikasi dan fenomena penggunaanya saja. Manun dampak dari pengguna, dan penyuka, hingga Pemerintah Indonesia harus siap dengan dampak yang akan muncul di kalangan masyarakatnya.

\section{METODE PENELITIAN}

Penelitian ini membahas apa yang melatar belakangi Aplikasi Tiktok menjadi sebuah media hiburan di tengah pandemi Covid-19. Melalui tahap pencarian data dari berbagai sumber. (Susilowati, 2018)

Metode penelitian yang digunakan adalah kualitatif dengan pendekatan jenis fenomenologi. Dengan fokus masalah Aplikasi Tiktok menjadi media hiburan bagi masyarakat di tengah pandemi Covid-19. Bidang kajian media massa, dan paradigma konstruktivis.

\section{Pengumpulan Data dan keterangan Sumber Data}

Teknik yang digunakan pengumpulan data yaitu dengan cara wawancara secara online. Wawancara melibatkan beberapa pengguna Tiktok. Pemilihan informan menggunakan teknik purposive dengan memperhatikan kriteria. Adapun kriteria informan adalah mahasiswa dan siswa pengguna aplikasi tiktok, yang berada pada rentang umur 14 tahun hingga 23 tahun. Selain wawancara, teknik pengumpulan data juga melalui metode dokumentasi.

\section{HASIL DAN PEMBAHASAN}

Pada tanggal 3 Mei 2020, virus Corana pertama kali masuk ke Indonesia. Masyarakat di himbau untuk tetap tenang dan selalu jaga kesehatan. Kepala negara Indonesia Presiden Jokowidodo atau dikenal Presiden Jokowi menyampaikan berita bahwa masyarakat untuk melakukan segala aktivitasnya dirumah saja, mulai dari sekolah, bekerja, bermain dan ibadah. PSBB pun mulai di berlakukan hampir diseluruh penjuru Indonesia. Peneliti mengamati prilaku yang dilakukan oleh masyarakat yang dihimbau untuk tetap dirumah. Kejadian ini adalah suatu fenomena yang tidak akan terjadi atau terulang karna adanya pandemi Covid-19.

Peneliti melakukan pengamatan dan wawancara terhadap beberapa siswa hingga tingkatan mahasiswa yang digantikan aktivitasnya di rumah saja. Peneliti melihat fenomena aplikasi tiktok menjadi media hiburan bagi beberapa kalangan. Dalam hal ini peneliti akan memaparkan hasil termuan yang ada dilapangan mengenai fenomena aplikasi tiktok yang berubah menjadi tempat berkreativitas sebagaian orang. Pertanyaan yang diberikan oleh peneliti yaitu tentang “Seberapa sering Anda menggunakan aplikasi tiktok?”, berikut ada diagram tanggapan informan yaitu : 
Menurut diagram dibawah dapat diartikan bahwa 88,9\% informan menggunakan aplikasi Tiktok hanya di waktu-waktu tertentu.

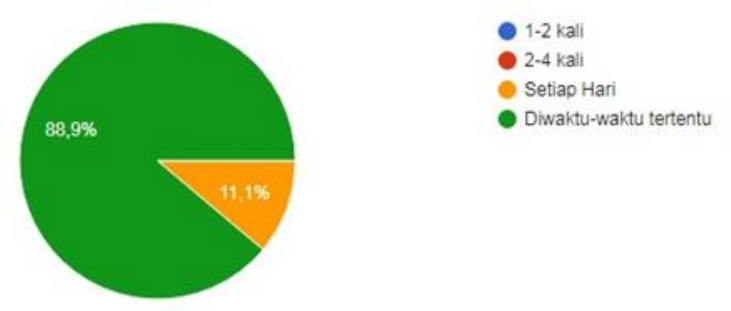

Gambar 1: Diagram Hasil Olahan Data

Setelah peneliti selesai dengan pertanyaan pertanya, selanjutnya peneliti pun melontarkan pertanyaan kedua yaitu "Untuk apa menggunakan aplikasi Tiktok?”, berikut jawaban dari semua informan yaitu seluruh informan menjawab sebagai media hiburan di tengah pandemi covid-19.

Selanjutnya peneliti melontarkan pertanyaan yang ketiga yaitu, "Apakah ada pengaruh besar setela menggunakan aplikasi Tiktok dalam kehidupa sehari-hari?"

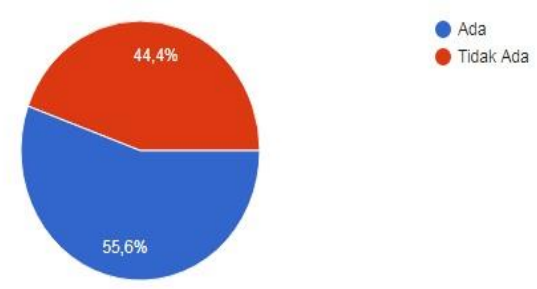

\section{Gambar 2: Diagram Hasil Olahan Data}

Sebagian informan menjawab ada pengaruh yang signifikan dan ada yang menjawab tidak ada pengaruh yang signifikan.

Selanjutnya peneliti melontarkan pertanyaan berikutnya, "Apakah ada keuntungan setelah menggunakan aplikasi Tiktok?", berikut jawabannya :

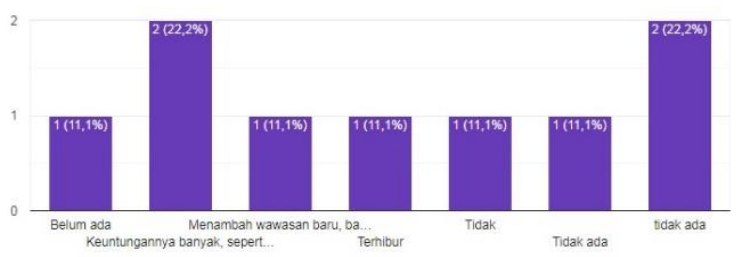

Gambar 3: Hasil Olahan Data

Kesimpulannya, dari 3 informan ada keuntungannya, salah satu informan menjawab aplikasi Tiktok menambah wawasan baru. 
Peneliti melontarkan pertanyaan terkahir yaitu, "Apakah aplikasi TikTok membuat kecanduan untuk terus membuat konten-konten yang lebih menarik?” jawaban informan sebagai berikut :

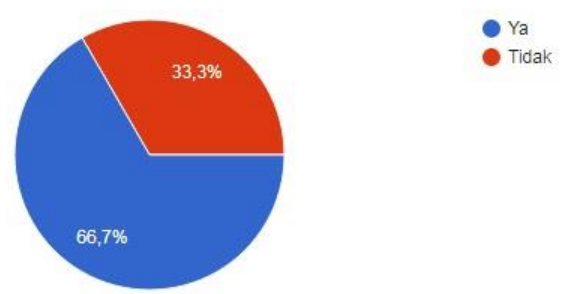

Gambar 2: Diagram Hasil Olahan Data

Hasil dari penelitian diatas ini mendapatkan fakta bahwa selama adanya pandemi Covid-19 ini mengakibatkan kecemasan semua orang, namun dengan adanya aplikasi Tiktok membantu beberapa bagian orang untuk tetap terhibur selama diam dirumah. Penggunaan aplikasi Tiktok ada beberapa manfaat yang merubah sebagian orang menjadi pribadi yang lebih kreatif dan aplikasi tiktok membagikan banyak fitur didalam nya.

\section{SIMPULAN}

Berdasarkan hasil penelitian, untuk mengetahui bagaimana fenomena aplikasi Tiktok di tengah pandemi Covid-19. Pada bagian akhir ini peneliti akan memaparkan kesimpulan yang dapat diambil berdasarkan penelitian yang telah dilakukan dan dianalisis pada bagian bab empat, maka peneliti menarik kesimpulan, bahwa ada perbedaan yang signifikan terhadap beberapa informan dengan adanya penggunaan aplikasi Tiktok ditengah pandemi Covid-19. Hampir semua informan menganggap bahwa aplikasi tiktok dapat menjadi hiduran, dan membuang kejenuhan saat PSBB berlangsung di penjuru Indonesia.

Peneliti berharap dengan adanya penelitian ini dapat membantu penelitian lanjutan yang akan memperkuat penelitian sebelumnya serta menambah hasil temuan terkait fenomena aplikasi Tiktok.

\section{DAFTAR PUSTAKA}

Andjani, M. D. (2009). Media Relation Sebagai Upaya Pembentukan Reputasi Organisasi. XLV.

Aprilian, H. R. (2019). No Title. PENGGUNAAN APLIKASI TIK TOK SEBAGAI AJANG EKSISTENSI DIRI (Studi Fenomenologi Pada Remaja Pengguna Aplikasi Tik Tok Di Jakarta).

Damayanti, T. dkk. (2019). Kajian Dampak Negatif Aplikasi Berbagi Video Bagi Anak-anak di Bawah Umur di Indonesia. 10.

Fauziah. (2019). Konsep Diri Remaja Penggunaan Tiktok di Kota Bandung. Universitas Komputer Indonesia.

Habibibullah. (2020). Mengenal Corona Virus Desease Tahun 2019 (COVID 19). smpitbanihasan.blogspot.com

Hakim, M. F. AL. (2020). PERBANDINGAN PARAMETER HEMOSTASIS PADA PASIEN COVID-19 DAN NON COVID-19

[Universitas

Sriwijaya]. https://repository.unsri.ac.id/40472/3/RAMA_11201_04011281722075_8862220016_0030065705_01_front ref.pdf

Ladimo, M. P. (2020). Middle East Respiratory SyndromeCorona Virus (MERS-CoV) Menggegerkan Dunia Bagian Timur. Gorontalo Journal, 4. https://ejurnal.ung.ac.id/index.php/gojhes/article/viewFile/4666/2124

Rahmawati, A. Y. (2019). Pengaruh Intensitas Menggunakan Aplikasi Tiktok Terhadap Perilaku Narsisme Remaja Muslim Komunitas Muser Jogja Squad. Universitas Islam Negeri Sunan Kalijaga. 
Setiawan, W. C. dkk. (2020). Strategi IMC Dalam Mempromosikan Program Internasional. Jurnal Scriptura, 10.

Susilowati. (2018). Pemanfaatan Aplikasi Tiktok Sebagai Personal Branding di Instagram. Ejournal.Bsi.Ac.Id, 9. http://ejournal.bsi.ac.id/ejurnal/index.php/jkom 